Creativity and Innovation Management, v14, (4), December 2005, pp334-344.

\title{
LEARNING FROM NEW PRODUCT DEVELOPMENT PROJECTS: AN EXPLORATORY STUDY
}

\author{
Ursula KONERS and Keith GOFFIN Cranfield School of Management, UK
}

\begin{abstract}
Knowledge generation is a cornerstone of new product development and post-project reviews (PPRs) are widely recognized as a facilitator of project-to-project learning. Empirical research on PPRs is sparse and so this paper describes four in-depth exploratory case studies which look at how PPRs are conducted and the learning that can result. The results indicate appropriately managed PPRs can make a significant contribution to knowledge generation and exchange. In addition, the study indicates the urgent need for more research into this important area.
\end{abstract}

\section{INTRODUCTION}

The challenge of new product development (NPD) is not only about the development of superior products. Managers also need to ensure that teams learn from each and every project and create new knowledge (Wheelwright and Clark, 1992). A post-project review (PPR) "is a formal review... which examines the lessons which may be learnt and used to the benefit of future projects" (Lane, 2000). Such reviews can help capture the knowledge generated during NPD. Practitioners and academics alike have stressed the importance of PPRs but, surprisingly, our understanding of how they are typically conducted or how learning can occur is limited.

There is wide anecdotal and some empirical evidence that not many organizations conduct PPRs (Bowen et al, 1994; Saban et al, 2000). Another issue to note is that the literature on organizational learning is very relevant but most researchers working in the NPD context have failed to consider these insights (McKee, 1992). This paper considers organizational learning issues and presents an investigation of PPRs in four companies, showing their potential to facilitate knowledge creation and learning.

\section{LITERATURE REVIEW AND THEORETICAL BASIS}

Three bodies of literature are relevant to this study: project management; research and development (R\&D) management; and organizational learning.

\section{Project Management Literature}

The need to formally review projects that have been completed was recognized at the end of the $1950 \mathrm{~s}$, parallel to the emergence of project management as a discipline (Weinberg and Freedman, 1984). By the 1970s, recommendations had started to appear on how to conduct PPRs (Gulliver, 1987). However, it is interesting to note that the well-known "Project Management Body of Knowledge (PMBOK)" (Project Management Institute, 1996) did not mention PPRs (Williams et al, 2001), until "lessons learned" was added to the glossary of a recent edition (Project Management Institute, 2000).

Three main advantages of PPRs are identified by the literature. Firstly learning from previous projects can help prevent similar mistakes (Pitman 1991, Ayas, 1997). Secondly, disseminating lessons learned is of critical importance (Ayas, 1997) and the methods most often mentioned include databases and rotation of 
personnel (Balthazor 1994, Holtshouse, 1999). Thirdly, every project needs to contribute to an organization's continuous improvement (Ayas 1997; Prahalad and Hamel, 1990).

\begin{tabular}{|c|c|c|c|}
\hline Source & Empirical Basis & Details / Critique of Methodology & Recommendations for PPRs \\
\hline $\begin{array}{l}\text { Baird et al } \\
\text { (1999) }\end{array}$ & $\begin{array}{l}\text { Anecdotal } \\
\text { examples from } \\
\text { USA army projects }\end{array}$ & $\begin{array}{l}\text { - No details given, only discusses } \\
\text { how the guidelines could be used } \\
\text { by companies }\end{array}$ & $\begin{array}{l}\text { Make the discussions objective } \\
\text { - } \quad \text { "Balance inquiry and advocacy" } \\
\text { Use inference to understand the issues }\end{array}$ \\
\hline $\begin{array}{l}\text { Busby } \\
(1999)\end{array}$ & $\begin{array}{l}4 \text { PPRs in three } \\
\text { different companies }\end{array}$ & $\begin{array}{l}\text { PPRs were observed and semi- } \\
\text { structured interviews conducted } \\
\text { with participants afterwards } \\
\text { It is unclear whether the study } \\
\text { was systematically conducted } \\
\text { No clear link between the } \\
\text { findings and the } \\
\text { recommendations }\end{array}$ & $\begin{array}{l}\text { Consider the whole project history } \\
\text { Make a detailed diagnosis and "plan } \\
\text { remedies properly" } \\
\text { Consider "the bigger system" } \\
\text { "Discourage glib categorisation" } \\
\text { "Invite key outsiders" }\end{array}$ \\
\hline $\begin{array}{l}\text { Right Track } \\
\text { Associates } \\
\text { (2002) }\end{array}$ & $\begin{array}{l}\text { Practical consulting } \\
\text { experience }\end{array}$ & No details given & $\begin{array}{l}\text { Analyze which procedures worked well } \\
\text { and which did not } \\
\text { Analyze which technical decisions were } \\
\text { effective and which were not } \\
\text { Ask: "was this project a good idea?" } \\
\text { Ask: "were sufficient skills and resources } \\
\text { available?" and "were resources utilised to } \\
\text { the fullest extent possible?" } \\
\text { Did the project achieve its goals... "in } \\
\text { terms of process and outcome?" }\end{array}$ \\
\hline $\begin{array}{l}\text { Schindler } \\
\text { and } \\
\text { Gassman } \\
(2000) ; \\
\text { Schindler } \\
\text { and Eppler } \\
(2003)\end{array}$ & $\begin{array}{l}\text { Action research in } \\
\text { nine multinational } \\
\text { companies }\end{array}$ & $\begin{array}{l}\text { Semi-structured expert interviews } \\
\text { Half-day follow-up workshops } \\
\text { Gives almost no details of the } \\
\text { methodology } \\
\text { Apparently no use of the } \\
\text { recognized approaches to action } \\
\text { research }\end{array}$ & $\begin{array}{l}\text { Capture the most important experiences } \\
\text { directly after each project milestone } \\
\text { "Have an external neutral moderator" } \\
\text { "Perform the lessons learned gathering } \\
\text { graphically" } \\
\text { "Ensure a collective, interactive } \\
\text { evaluation" } \\
\text { Get commitment to apply the insights } \\
\text { gained } \\
\text { Instigate a "project knowledge broker" }\end{array}$ \\
\hline
\end{tabular}

Table 1: Guidelines for Conducting PPRs in the Project Management Literature

The literature also includes recommendations for conducting PPRs and Table 1 gives an overview of these. Some of these are quite vague (e.g. "discourage glib categorization"; Busby, 1999), whereas others are specific. For example, Schindler recommended a "project knowledge broker", responsible for transferring the lessons learnt within and between project teams (Schindler and Gassmann 2000; Schindler and Eppler, 2003). A key problem is that the studies have not been conducted systematically and so the validity of the recommendations is questionable.

\section{R\&D Literature}

Knowledge is the main source of long-term competitive advantage in R\&D (Corso et al, 2001). Therefore, the emphasis on learning from new product development projects is made by several authors (e.g. Bowen et al, 1994; Leonard-Barton, 1992; Liyanage et al, 1999). PPRs are widely recognized as an important but seldom used mechanism for learning (Wheelwright and Clark, 1992; Bowen et al, 1994; von Krogh, 1998; Bourgault and Sicotte, 1998; Cooper, 1999).

Three empirical articles have established that the use of PPRs in R\&D organizations is limited. One showed that only two out of 33 microelectronic manufacturers use PPRs and mostly only for "radical" development projects (Boag and Rinholm 1989). Goffin and Pfeiffer (1999) found that four of their 16 case study 
companies used PPRs but failed to give details on how they were used. A survey of 63 R\&D managers identified that only $3 \%$ of their organizations conduct a PPR after every project but the majority of them $(94 \%)$ think their organizations should conduct PPRs (von Zedtwitz, 2002).

Even though their importance has been recognized, our understanding of PPRs has a weak empirical base, as is demonstrated by Table 2. It can be seen that the four main papers are either based on small samples, or the personal experience of the author. The recommendations have not been derived directly from the data and so it is unclear how applicable they are. Moreover, the recommendations focus on knowledge that can be written down, documented and easily shared. There is no advice on how the PPRs can be used to share experiences which are more difficult to articulate or document. Additionally, the papers are not based on learning theory: "academic research on innovation has a strong learning orientation. The problem is that much of the work that has been done is not organized in terms of underlying learning theory" (McKee, 1992). Consequently, there is a need to introduce an organizational learning perspective.

\begin{tabular}{|c|c|c|c|}
\hline Reference & Empirical basis & $\begin{array}{l}\text { Details / Critique of } \\
\text { Methodology }\end{array}$ & Recommendations for PPRs \\
\hline $\begin{array}{c}\text { Duarte and } \\
\text { Snyder (1997) }\end{array}$ & $\begin{array}{l}\text { Single case study - } \\
\text { Whirlpool }\end{array}$ & $\begin{array}{r}\text { Action research } \\
\text { using } \\
\text { product development } \\
\text { learning template } \\
\text { Claims to be } \\
\text { partially } \\
\text { based on Huber's } \\
\text { organizational } \\
\text { learning model - but it } \\
\text { is unclear how }\end{array}$ & $\begin{array}{l}\text { Document what went well and what needs } \\
\text { improvement - at every stage in the process } \\
\text { - Discuss openly what happened and why } \\
\text { - Focus on the assumptions and the process used by } \\
\text { the team } \\
\text { - Obtain as many different perspectives as possible } \\
\text { - Be open to multiple interpretations and a systems } \\
\text { perspective } \\
\text { - Suggest a range of options for improvement }\end{array}$ \\
\hline $\begin{array}{l}\text { Lilly and } \\
\text { Porter (2003) }\end{array}$ & $\begin{array}{l}\text { Two stage research } \\
\text { in various } \\
\text { organizations }\end{array}$ & $\begin{array}{l}\text { Exploratory } \\
\text { interviews with } 16 \\
\text { NPD managers in } \\
\text { eight companies } \\
\text { Mail survey across } 49 \\
\text { companies } \\
\text { Focus of research is } \\
\text { explicit knowledge }\end{array}$ & $\begin{array}{l}\text { - "Incorporate reviews as a standard part of the } \\
\text { development process" } \\
\text { "Formalized review procedures lead to fewer } \\
\text { individual learning biases" } \\
\text { "Having multiple perspectives in the review } \\
\text { process is very important" } \\
\text { "Conducting only a single review minimizes the } \\
\text { ability to effectively learn from the project } \\
\text { experiences" } \\
\text { "Learning that does occur is often not fully shared" }\end{array}$ \\
\hline Smith (1996) & $\begin{array}{l}\text { Anecdotal } \\
\text { examples from nine } \\
\text { companies }\end{array}$ & $\begin{array}{l}\text { No details given } \\
\text { Apparently no } \\
\text { systematic approach }\end{array}$ & $\begin{array}{l}\text { Review every project } \\
\text { Assign a reviewer } \\
\text { Define a review process } \\
\text { Identify strengths } \\
\text { Constructively balance positive and negative } \\
\text { findings } \\
\text { Focus on process improvements } \\
\text { Interview key participants and back up the } \\
\text { interview with the data } \\
\text { Use metrics }\end{array}$ \\
\hline $\begin{array}{l}\text { Wheelwright } \\
\text { and Clark } \\
(1992)\end{array}$ & $\begin{array}{l}\text { Various case } \\
\text { studies }\end{array}$ & $\begin{array}{l}\text { Few details given of } \\
\text { the selection of cases, } \\
\text { or how they were } \\
\text { studied }\end{array}$ & $\begin{array}{ll}\text { Sample question regarding: } \\
\text { - } & \text { Project background } \\
\text { Pre-project activities } \\
\text { - } \\
\text { Project team } \\
\text { Project management } \\
\text { - Senior management review and control } \\
\text { Protoype and tests }\end{array}$ \\
\hline
\end{tabular}

Table 2: Guidelines for Conducting PPRs in the R\&D Management Literature 


\section{Organizational Learning}

This literature focuses on the concept of "knowledge", which was largely introduced by Nonaka (1994), who indicated that there are two types of knowledge: "explicit" and "tacit". Explicit knowledge is easy to explain and document, whereas tacit knowledge is difficult to articulate. Although it is possible to distinguish theoretically between them, they are hard to differentiate in practice (Lam 2000; Brown and Duguid, 1991). Nonaka concluded that knowledge always has a tacit component that is largely shared through social processes. "In project work... a great deal of the know-how required is tied to knowledge that is not written in documents but realised through the expertise and understanding of the project personnel" (Koskinen et al, 2003).

Nonaka (1994) identified various mechanisms for the generation and transfer of knowledge, including the central role of metaphors and stories in discussions. Groups of people who are informally bound to one another by exposure to a common class of problems ("communities of practice") are able to exchange knowledge with little verbal or written communication (Wenger and Snyder, 2000). Therefore knowledge especially tacit knowledge - is often created and shared within a group setting (Sapsed et al, 2000).

Although social interactions, metaphors and stories are key exchange mechanisms, the literature (e.g. Nonaka) gives only anecdotal examples and no guidance on how to operationalize these concepts.

\section{Conclusions on the Literature}

The literature on PPRs in a NPD (i.e. R\&D) context is currently limited to statements on their importance, some indication that not many organizations use them, and untested guidelines. Very few researchers have considered the organizational learning literature, which demonstrates the tacit and social sides of learning. Overall, there is a need for empirical studies of both how PPRs are conducted and how they can promote learning.

\section{RESEARCH DESIGN \\ Research Questions}

Based on the gaps in the literature, a number of research questions were developed, two of which are presented here:

1) How do companies conduct post-project reviews?

2) What is the potential for both explicit and tacit learning from PPRs?

\section{Methodology}

In-depth case studies were selected as the most appropriate methodology for the exploratory research on PPRs for three reasons. Firstly, case studies are most often found when researching complex social phenomena in real-life contexts (Yin, 1994). Secondly, the limited amount of previous research on PPRs means that themes and patterns need to be identified (Eisenhard, 1989). Thirdly, case studies allow us to look at formal as well as informal processes within an organization and enable the researcher to look at a wide array of variables (Hartley, 1994).

\section{Sample}

The sampling frame was large companies in the south of Germany, which is considered to be a leading high-tech region because it accounts for the highest number of patents and R\&D investments per capita (Staatsministerium Baden- 
Württemberg, 2001). The four companies chosen will, for reasons of confidentiality, be designated EngineeringCo, AppliancesCo, MedCareCo and MachineryCo.

\section{Data Sources}

Due to complex nature of knowledge and learning, multiple sources of data were used and Figure 1 gives an overview. The documents obtained included guidelines for PPRs in companies' NPD process documentation and minutes of specific PPRs, which were all analyzed by content. Secondly, six interviews with NPD project managers and participants were conducted at each company, using both a structured and semistructured approach. A structured repertory grid interview was used as this technique is particularly useful when interviewees find it difficult to articulate their views on complex topics (Goffin, 2002). This method identified key "lessons learned" from completed projects. The rest of each interview was used for a semi-structured questionnaire on how PPRs are run (e.g. the timing, location and focus of discussions etc). Finally, one PPR was observed at each company and analyzed using a framework based on organizational learning concepts. Meeting transcripts were checked with a particular focus on stories and metaphors, as evidence for tacit knowledge creation and transfer. Overall, the multiple sources of data allowed a high degree of triangulation as each aspect of PPRs could be studied from different perspectives.

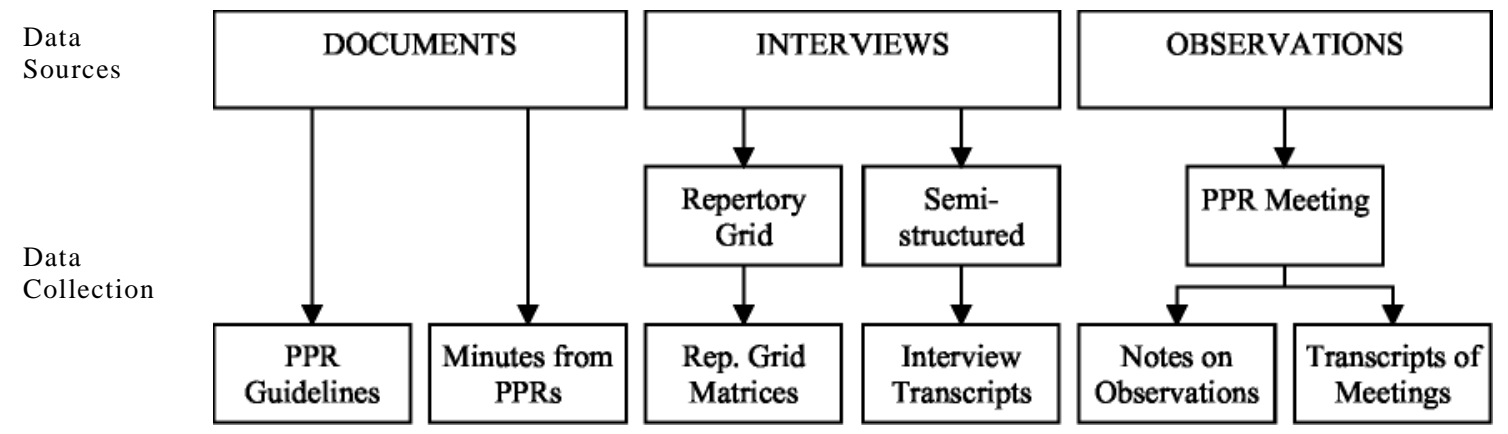

Figure 1: Overview of data sources within each case study

\section{CROSS CASE ANALYSIS \\ Current PPR practices}

The analysis of PPR practices was based on the company documents, the interviews and the observations of PPRs and conducted by the two authors in unison. Table 3 shows the evidence for nine key characteristics across the four case studies. These characteristics were derived from ideas in the literature and an inductive process based on the data 


\begin{tabular}{|c|c|c|c|c|c|c|}
\hline & \begin{tabular}{|c|}
$\begin{array}{c}\text { Characteristics } \\
\text { of PPRs }\end{array}$ \\
\end{tabular} & EngineeringCo & AppliancesCo & MedCareCo & MachineryCo & $\begin{array}{l}\text { Conclusions / Our } \\
\text { recommendations }\end{array}$ \\
\hline & Timing & $\begin{array}{l}\text { Guideline is } \\
\text { approximately } 6 \text { months } \\
\text { after market launch but } \\
\text { later in practice. }\end{array}$ & $\begin{array}{l}\text { Guideline is directly } \\
\text { after market launch. In } \\
\text { practice at least } 6 \\
\text { months later. }\end{array}$ & $\begin{array}{l}\text { Guideline is } 6 \text { months } \\
\text { after market launch. In } \\
\text { practice sometimes } \\
\text { earlier because of time } \\
\text { pressure or senior } \\
\text { management priorities. }\end{array}$ & $\begin{array}{l}\text { Guideline is } 6 \text { months } \\
\text { after market } \\
\text { introduction. In } \\
\text { practice often later } \\
\text { because of availability } \\
\text { of the necessary } \\
\text { participants. }\end{array}$ & $\begin{array}{l}\text { Guidelines are not } \\
\text { usually followed } \\
6 \text { months after } \\
\text { launch appears } \\
\text { appropriate }\end{array}$ \\
\hline & Participants & Core project team & $\begin{array}{l}\text { Project team with } \\
\text { moderator from outside } \\
\text { the project. Final } \\
\text { presentation is to senior } \\
\text { management. }\end{array}$ & $\begin{array}{l}\text { Full project team. For } \\
\text { strategic projects the } \\
\text { steering committee is } \\
\text { also present. }\end{array}$ & Core project team & $\begin{array}{l}\text { Core team is } \\
\text { always present. } \\
\text { The presence of } \\
\text { senior } \\
\text { management at } \\
\text { the presentation } \\
\text { motivates and also } \\
\text { helps disseminate } \\
\text { knowledge }\end{array}$ \\
\hline & Location & Meeting room & $\begin{array}{l}\text { External training } \\
\text { centre }\end{array}$ & Meeting room & $\begin{array}{l}\text { Meeting room or social } \\
\text { setting (e.g. room in a } \\
\text { restaurant) }\end{array}$ & $\begin{array}{l}\text { Separate meeting } \\
\text { rooms are always } \\
\text { used. } \\
\text { External meetings } \\
\text { stimulate open } \\
\text { discussion and } \\
\text { avoid interruptions }\end{array}$ \\
\hline & Moderation & Project manager & $\begin{array}{l}\text { Moderator from } \\
\text { internal training unit }\end{array}$ & $\begin{array}{l}\text { In some cases internal } \\
\text { auditor }\end{array}$ & Project manager & $\begin{array}{l}\text { Usually project } \\
\text { managers } \\
\text { moderate } \\
\text { An external } \\
\text { experienced } \\
\text { moderator can } \\
\text { stimulate more } \\
\text { effective discussion }\end{array}$ \\
\hline & Duration & Max. three hours & Full day & Max. two hours & One hour & $\begin{array}{l}\text { The length of PPRs } \\
\text { varies } \\
\text { Take sufficient } \\
\text { time for a detailed }\end{array}$ \\
\hline
\end{tabular}




\begin{tabular}{|c|c|c|c|c|c|c|}
\hline & & & & & & discussion \\
\hline 6. & $\begin{array}{l}\text { Focus of } \\
\text { discussion }\end{array}$ & $\begin{array}{l}\text { Problems with each } \\
\text { project phase, the } \\
\text { schedule and capacity }\end{array}$ & $\begin{array}{l}\text { Problems but also their } \\
\text { causes and } \\
\text { consequences and } \\
\text { important experiences } \\
\text { for future projects }\end{array}$ & $\begin{array}{l}\text { Problems and figures } \\
\text { achieved, feedback from } \\
\text { the team for project } \\
\text { manager }\end{array}$ & $\begin{array}{l}\text { Positive and negative } \\
\text { issues, outstanding } \\
\text { actions, improvement } \\
\text { suggestions }\end{array}$ & $\begin{array}{l}\text { - The focus is nearly } \\
\text { always on } \\
\text { problems } \\
\text { - The mechanisms } \\
\text { that led to project } \\
\text { success also need } \\
\text { consideration }\end{array}$ \\
\hline & $\begin{array}{l}\text { Actions taken to } \\
\text { stimulate } \\
\text { knowledge } \\
\text { generation }\end{array}$ & $\begin{array}{l}\text { Discussion of causes and } \\
\text { consequences after a } \\
\text { round of feedback from } \\
\text { the team }\end{array}$ & $\begin{array}{l}\text { Personal satisfaction } \\
\text { curves, causal mapping } \\
\text { and many opportunities } \\
\text { for story telling and } \\
\text { metaphors during the } \\
\text { day }\end{array}$ & None identified & $\begin{array}{l}\text { Deep discussion of } \\
\text { personal experiences } \\
\text { within the team based } \\
\text { on questions from } \\
\text { project manager and } \\
\text { facilitated by the social } \\
\text { setting }\end{array}$ & $\begin{array}{l}\text { The location and } \\
\text { moderation } \\
\text { influence this } \\
\text { Companies should } \\
\text { consciously try and } \\
\text { support the } \\
\text { exchange of } \\
\text { knowledge }\end{array}$ \\
\hline & Documentation & $\begin{array}{l}\text { Short report only, as the } \\
\text { focus is on the discussion } \\
\text { itself and not on } \\
\text { documenting it }\end{array}$ & $\begin{array}{l}\text { PPR report with } \\
\text { suggestions and a } \\
\text { presentation to senior } \\
\text { management }\end{array}$ & $\begin{array}{l}\text { PPR minutes as well as } \\
\text { action points to follow } \\
\text { up }\end{array}$ & $\begin{array}{l}\text { Final report to steering } \\
\text { committee with three } \\
\text { lessons learnt }\end{array}$ & $\begin{array}{l}\text { Reports or minutes } \\
\text { are normal. One } \\
\text { company has a } \\
\text { presentation to } \\
\text { management } \\
\text { Specific actions are } \\
\text { needed to } \\
\text { guarantee } \\
\text { knowledge transfer }\end{array}$ \\
\hline & $\begin{array}{l}\text { Dissemination of } \\
\text { results }\end{array}$ & $\begin{array}{l}\text { Information stays within } \\
\text { the project team and } \\
\text { learning is seldom } \\
\text { followed up. }\end{array}$ & $\begin{array}{l}\text { Report is distributed } \\
\text { across business units. } \\
\text { Follow-up by top } \\
\text { management does not } \\
\text { really happen. }\end{array}$ & $\begin{array}{l}\text { Very limited outside of } \\
\text { the project team. } \\
\text { Minutes go to a steering } \\
\text { committee. }\end{array}$ & $\begin{array}{l}\text { Report goes to project } \\
\text { team and steering } \\
\text { committee, with a } \\
\text { follow-up of action } \\
\text { points by project } \\
\text { manager. }\end{array}$ & $\begin{array}{l}\text { Lessons learnt } \\
\text { often stay with } \\
\text { project team } \\
\text { Management } \\
\text { needs to instigate } \\
\text { effective } \\
\text { dissemination } \\
\text { mechanisms } \\
\text { including the use } \\
\text { of stories and } \\
\text { metaphors }\end{array}$ \\
\hline
\end{tabular}

Table 3: Selected Key Characteristics of PPRs 
Table 3 shows that three companies' guidelines specify PPRs should be held 6 months after the product introduction in order to include information about the market acceptance. However, in practice PPRs take place later because of difficulties to set a date for all participants - this was established by data from the minutes of PPRs and the interviews being contrasted with the company NPD process documentation. The core team is normally gathered in an internal meeting room but the use of an 'off-site' approach appears to be positive in setting an appropriate atmosphere for team learning: "...for me personally the PPR is a gathering of experiences. By participating in a project and in a PPR you learn automatically and are supported by others" (Interviewee 3 EngineeringCo). Concluding the PPR with a team celebratory meal (e.g. MachineryCo) also appears to reinforce team learning. Although three companies assign the project manager to moderate, using an experienced moderator from outside the team appears likely to be more effective "A good moderator can cope better with people who for example go on about the same thing for ages. The ones we have are really good, know what they are talking about and how to stimulate the discussion" (Interviewee 4 Appliances Co). The time invested in a PPR needs to be sufficient to achieve knowledge generation through detailed discussions. The exact time required depends on the complexity of the project in question. The interest and support of senior management has a big influence on the time and effort invested in PPRs. This is evident at ApplicancesCo, where the Chief Technology Officer introduced the PPR process, and a full day is invested using an internal trainer as a moderator. The results are then presented to senior management.

Across all four cases it is interesting to see that the discussion is mainly focused on project problems: "...of course there are always some issues that everyone is surprised about how they develop into big problems during the PPR discussion without anyone realizing their importance before" (Interviewee 2 MedcareCo). The focus on problems implies that mainly lessons on how to avoid problems will be disseminated rather than successful practices. At three of the companies the moderator guided discussions in a way that appear to support knowledge generation and discussions. Examples included discussions based on root cause analysis (e.g. EngineeringCo) and drawing 'personal satisfaction curves' (AppliancesCo). Project team discussions are perceived as enlightening: “...yes, I am always surprised what you learn during a meeting like that...there are always new aspects of which I was not really aware of before" (Interviewee 6 AppliancesCo).

All case companies produce a formal report from the PPR but the dissemination appears to be weak with little follow-up on action points. This means that much of the learning is not transferred effectively to other projects. It was often mentioned that the PPR itself is the most important dissemination tool and less focus should be put on written documentation: "how can I write this down, I know we understand it in the team without any discussion, but for outsiders this might not be clear at all..." (Observation of the PPR at EngineeringCo)

The right-hand column of Table 3 gives recommendations based directly on the research. These include the timing, the use of an external moderator, stimulating effective discussions, the follow up of action points and the transfer of findings to future projects. These should enable R\&D managers to improve NPD project-toproject learning.

\section{The Potential for Knowledge Creation}


Our results strongly indicate the potential for learning from PPRs and we will give two categories of examples: quotes from the interviews and an analysis of metaphors used in the PPRs observed.

Interviewees often discussed how much they learnt in PPRs that was not documented in the minutes (this was confirmed by triangulation with these documents). For example, "I learnt that you do not always have to fill huge files after a PPR. If you have a good team and reflect collectively on each topic, it works just by the common understanding of these people." (Interviewee 5 MedcareCo). The tacit nature of much of this learning is typified by the following quote: "I think lessons learned I can only disseminate if I register it myself and then use it again in the projects I work in and like that pass the experience on to my colleagues" (Interviewee 3 MachineryCo).

The second indication of the tacit nature of knowledge generated and exchanged in PPRs is the usage of metaphors. Table 4 shows that in the 15 hours of PPRs observed, a total of 55 metaphors were used. This means that metaphors and stories emerged on average nearly every 15 minutes of discussion. One example stems from the PPR at Engineering Co, where a participant said, "we are always at the very end of the food chain unfortunately" meaning that he was responsible for the final assembly of products and therefore vulnerable to suffering from all of the problems that were experienced during earlier project phases. Various metaphors were heard at AppliancesCo, including "Reichsbedenkenträger" (German metaphor for someone who has strong doubts about everything 'Minister of Doubt') - referring to someone who constantly challenged the team's plans. This is the first time that empirical data on the level of usage of metaphors in PPRs has been collected and so there is no benchmark as to whether the case companies use metaphors more than other NPD teams. Our analysis shows that PPR participants use metaphors in various ways: to stimulate discussion (observed 12 times), in the middle of a topic, towards the end, or as an aside. Often metaphors lightened the atmosphere or allowed sensitive points to be discussed in a non-threatening way.

\begin{tabular}{|l|c|c|c|c|c|c|}
\hline Case & $\begin{array}{c}\text { Length of } \\
\text { observed } \\
\text { PPR }\end{array}$ & \multicolumn{2}{|c|}{$\begin{array}{c}\text { Number of } \\
\text { metaphors } \\
\text { identified }\end{array}$} & \multicolumn{3}{|c|}{ Place of metaphors and stories in the discussion } \\
\hline & & & \multicolumn{2}{|c|}{ A id } & \multicolumn{2}{|c|}{ End } \\
\hline EngineeringCo & 2,5 hours & 14 & 3 & & 5 & 6 \\
\hline AppliancesCo & 7,5 hours & 30 & 6 & 6 & 13 & 5 \\
\hline MedCareCo & 3 hours & 5 & 1 & 1 & 2 & 1 \\
\hline MachineryCo & 2 hours & 6 & 2 & 3 & & 1 \\
\hline Total & $\mathbf{1 5}$ hours & $\mathbf{5 5}$ & $\mathbf{1 2}$ & $\mathbf{1 0}$ & $\mathbf{2 0}$ & $\mathbf{1 3}$ \\
\hline
\end{tabular}

Table 4: Metaphors and Stories used during PPR discussions

Overall, statements from interviewees about what and how they learned in PPRs and the use of metaphors and stories can be taken as tentative evidence for the creation and transfer of tacit knowledge. 


\section{DISCUSSION}

Investigating how four companies conduct PPRs using multiple data sources provides a depth of understanding that was previously missing. This allows clearer recommendations to be made about how PPRs should be organized and how discussions can be stimulated. The minutes of PPRs show a focus on explicit knowledge, such as project management issues (e.g. schedule, cost and quality) and the technical lessons learned (e.g. problems solved). However, interviews with NPD engineers and managers indicate that far more can be learnt from projects, such as better ways to communicate. PPRs have the potential to stimulate learning. However, across all four companies the learning from PPRs is currently only disseminated effectively to the people who participate in the meeting. Although documentation is produced, this is not an effective mechanism and action points do not seem to be followed up efficiently.

Based on the research, the main recommendations for practitioners are (see also Table 3):

- Six months after product introduction sufficient time needs to be allocated to a detailed of both the success and problems encountered on the project. A moderator from outside the team and a suitable location are important to set the right atmosphere for knowledge generation;

- The moderator needs to take steps to try and stimulate the exchange of tacit knowledge and focusing on metaphors and stories may help;

- Management needs to design suitable mechanisms for the dissemination of the results of PPRs across their whole organization; otherwise much of the effort will be wasted. Effective dissemination consists of more than minutes and reports from PPRs. Encouraging social interactions between different project teams may help and using stories to summarize the key learning could well be more effective than just formal reports;

- NPD team members view PPRs positively and they can be an ideal opportunity to celebrate success.

For NPD researchers there are some important implications:

- Project-to-project learning has been given too little attention in the past;

- There is a need to understand what the frequency of usage of PPRs is and how they are typically conducted;

- The exact nature of the lessons learned in PPRs must be investigated (and here we have the opportunity to analyze other aspects of our data);

- Our understanding of how knowledge is generated in NPD is only just emerging. However, NPD researchers could and should take a lead in investigating how tacit knowledge is generated and how it can be observed (i.e operationalized).

Overall, the research confirms the learning potential of PPR's and, as one interviewee stated: "only in such a group with people from diferent functions...[can] you always learn something you did not know before” (Interviewee 3 AppliancesCo). 


\section{REFERENCES}

1. Ayas, K. (1997). Integrating corporate learning with project management. International Journal of Production Economics, 51, 5 9-67.

2. Baird, L., Holland, P., Deacon, S., (1999). Learning from action: imbedding more learning into the performance fast enough to make a difference. Organizational Dynamics, Spring 1999, 19-31.

3. Balthazor, L.R. (1994). Project review - do you really know where you are? The Aeronautical Journal, 98(973).

4. Boag, D.A., Rinholm, B.L. (1989). New product management practices of small high technology firms. Journal of Product Innovation management. 6(2), 109-122.

5. Bourgault, M., Sicotte, H. (1998). Learning conditions and performance of development projects: empirical evidence from a research center. In:

Proceedings of the $29^{\text {th }}$ annual project management institute 1998 Seminars \& Symposium, October 9-15 1998, Long Beach, California.

6. Bowen, H.K., Clark, K.B., Wheelwright, S.C. (1994). Development projects: the engine of renewal. Harvard Business Review, 72(5), 110-119.

7. Brown, J. S., Duguid, P. (1991). Organizational learning and communities of practice: toward a unified view of working, learning and innovation. Organization Science, 2(1), 40-57.

8. Busby, J.S. (1999). An assessment of post-project reviews. Project Management Journal, 30(3), 23-29.

9. Cooper, R. G. (1999). From Experience: the invisible success factors in product innovation. Journal of Product Innovation Management, 16(2), 115133.

10. Corso, M.; Martini, A.; Paolucci, E.; Pellegrini, L. (2001). Knowledge management in product innovation: an interpretative review. International Journal of Management Review, 3(4), 341-352.

11. Duarte, D.; Snyder, N. (1997). From Experience: facilitating global organizational learning in product development at Whirlpool corporation. Journal of Product Innovation Management, 14(1), 48-55.

12. Eisenhard, K. M. (1989). Building theories from case study research. Academy of Management Review, 14(4), 532-550.

13. Goffin and Pfeiffer (1999) Innovation Management in UK and German Manufacturing Companies. Anglo-German Foundation Report Series, ISBN 1900834-17-0, 70pp, London.

14. Goffin, K. (2002) Repertory Grid Technique. In: Partington, D. (ed.) Essential skills for management research. Sage Publications, London. pp. 198-225

15. Gulliver, F. R. (1987). Post-Project appraisals pay. Harvard Business Review, 87(2), 128-132.

16. Hartley, J. F. (1994). Case studies in organizational research. In: Cassell, C. (eds.) Qualitative methods in organizational research: a practical guide. Sage, London.

17. Holtshouse, D. (1999). Ten knowledge domains: model of a knowledgedriven company. Knowledge and Process Management, 6(1), 3-8.

18. Koskinen, K.U.; Pihlanto, P.; Vanhoranta, H. (2003). Tacit knowledge acquisition and sharing in a project work context. International Journal of Project Management, 21(4), 281-290. 
19. Lam, A. (2000). Tacit knowledge, organizational learning and societal institutions: an integrated framework. Organization Studies, 2 1(3), 487-5 13.

20. Lane, Ken (ed) (2000). Project Management Today, www.projectnet.com, 2.2.2000.

21. Leonard-Barton, D. (1992). Core capabilities and core rigidities: a paradox in managing new product development. Strategic Management Journal, 13, Special Issue, 111-125.

22. Lilly, B.; Porter, T. (2003). Improvement reviews in new product development. $R \& D$ Management, 33(3), 285-296.

23. Liyanage, S., Greenfield, P. F., Dan, R. (1999). Towards a fourth generation R\&D management model - research networks in knowledge management. International Journal of Technology Management, 18(3/4), 372-3 93.

24. McKee, C. (1992). An organizational learning approach to product innovation. Journal of Product Innovation Management, 9(3), 232-245.

25. Nonaka, I. (1994). A dynamic theory of organizational knowledge creation. Organization Science, 5(1), 14-37.

26. Pitman, B. (1991). A systems analysis approach to reviewing completed projects. Journal of systems management, 42(6).

27. Prahalad, C.K. Hamel, G. (1990). The core competence of the corporation. Harvard Business Review, 68(3), 79-.

28. Project Management Institute (1996). A guide to the project management body of knowledge, Project management Institute, PA, USA.

29. Project Management Institute (2000). A guide to the project management body of knowledge, Project management Institute, PA, USA.

30. Right Track Associates (2000) "Post project reviews: analyzing lessons learned". Right Track Asoociates, www.ITtoolkit.com.

31. Saban, K., Lamosa, J., Lackman, C., Peace, G. (2000). Organizational learning: a critical component to new product development. Journal of product and brand management, 9(2), 99-119.

32. Sapsed, J., Bessant, J., Partington, D., Tranfield, D., Young, M. (2000). From IT to Teams: Trends in the management of organisational knowledge. R\&D Management Conference 2000: Wealth from Knowledge: Innovation in R\&D Management, Manchester, UK, July 10-12.

33. Schindler, M., Gassmann, O. (2000). Wissensmanagement in der Proj ektabwicklung. Wissenschaftsmanagement.

34. Schindler, M.; Eppler, M.J. (2003). Harvesting project knowledge: a review of project learning methods and success factors. International Journal of Project Management, 21(3), 219-228.

35. Smith, P. G. (1996). Your product development process demands ongoing improvement. Research Technology Management, 39(2), 37-44.

36. Staatsministerium Baden Württemberg (2001). www.baden-württemberg.de, 22.5.2001.

37. Von Krogh, G. (1998). Care in knowledge creation. California Management Review, 40(3), 133-153.

38. Von Zedtwitz, M. (2002). Organizational learning through post-project reviews in R\&D. $R \& D$ Management, 32(3), 255-268.

39. Weinberg, G. M., Freedman, D. P. (1984). Reviews, Walkthroughs and Inspections. IEEE Transactions on Software Engineering, 10(1).

40. Wenger, E., Snyder, W. M. (2000). Communities of practice: the organizational frontier. Harvard Business Review, 78(1), 139-145. 
41. Wheelwright, S. C., Clark, K. B. (1992). Revolutionizing product development: Quantum leaps in speed, eficiency and quality. The free press, New York.

42. Williams, T.; Eden, C.; Ackermann, F.; Howick, S. (2001). "The use of project post-mortems". Strathclyde Business School, Research paper no. 2001/7.

43. Yin, R. K. (1994). Case study research: design and methods. Sage publications, Applied Social Research Methods Series Volume 5, Second Edition. 